Review Article

\section{Do genes matter in sleep?-A comprehensive update}

\author{
Rajib Dutta* \\ MD Neurology, India
}

\section{Abstract}

Sleep is considered as a complex process in human beings and is least understood mechanism. Role of sleep in synaptic plasticity remains a debatable topic till date. Sleep is influenced by genetic background of the individual. EEG done in human sleep showed strong influence of genetic factors. A handful of familial analyses involving specific gene loci and twin studies has been done in this regard. In this review article focused discussion on genetic contribution to sleep phenotypes, twin and familial linkage studies and effect of genetic variation on sleep will be covered.

\section{Introduction}

Human being need to rest on a daily basis. Lack of rest leads to severe physical and psychological symptoms which can lead to behavioral inactivity. Pathobiology and molecular mechanisms involved in sleep is quite complex and least understood phenomenon according to many researchers. Sleep studies and researches has gained a lot of momentum in recent years. The main reason is role of genetic background which can disrupt sleep and thereby causing several types of sleep disorders reported in literature till date [1].

Variation of sleep phenotypes, their intraindividual stability as well as familial aggregation of certain sleep related disorders has drawn a lot of attention recently. Human sleep EEG showed evidence that it is dependent on genetic background of the individual in question which led many to think that human EEG is highly heritable trait in human beings [2,3]. Heritability of sleep traits is controlled by genetic polymorphism and regulation [4-8]. Relation of sleep with age, gender, environment still needs to be elicited in ongoing studies. Molecular processes and function that produce the need to sleep both remain understudied $[9,10]$.

Major advances in the recent years comprise the identification of brain structures, neurotransmitters and several other molecules regulating sleep and common understanding among clinicians and researchers that it is quite a common treatable phenomenon which when unaddressed can cause severe psychosomatic and cognitive symptoms that can affect quality of life in individuals irrespective of age, gender and other confounding factors [11-14].

\section{More Information}

\begin{abstract}
*Address for Correspondence: Rajib Dutta, MD Neurology, India, Email: rajibdutta808@gmail.com

Submitted: 24 February 2020

Approved: 04 March 2020

Published: 05 March 2020

How to cite this article: Dutta R. Do genes matter in sleep?-A comprehensive update. J Neurosci Neurol Disord. 2020; 4: 014-023.
\end{abstract}

DOI: 10.29328/journal.jnnd.1001029

ORCiD: orcid.org/0000-0002-6129-1038

Copyright: @ 2020 Dutta R. This is an open access article distributed under the Creative Commons Attribution License, which permits unrestricted use, distribution, and reproduction in any medium, provided the original work is properly cited.

Keywords: Sleep; Gene loci; Genetics

Abbreviations: EEG: Electroencephalogram; PSG Polysomnogram; REM: Rapid Eye Movement; NREM: Non Rapid Eye Movement; AD: Autosomal Dominant; AR: Autosomal Recessive; RLS: Restless Leg Syndrome; SNP: Single Nucleotide Polymorphisms; VNTR: Variable Number Tandem Repeat; MAO: Monoamine Oxidases; COMT: Catechol-O-Methyltransferase; TNF: Tumor Necrosis Factor; BDNF: Brain-Derived Neurotrophic Factor; SLC: Solute Carrier Family 6 Member 3; ADA: Adenosine deaminase; PRNP: Prion Protein Gene; GNAZ: Guanine Nucleotidebinding protein $\mathrm{G}(\mathrm{z})$ subunit alpha

Check for updates

OPEN ACCESS

Previously twin studies has reported higher concordance of sleep habits, e.g. sleep duration and quality in monozygotic (MZ) than in dizygotic (DZ) twins, even when exposed to different environmental situation with an estimated heritability of 30\%-44\% [15-19]. Pittsburgh Sleep Quality Index (PSQI) is usually used to investigate subjective sleep quality [20]. Zung, et al. performed the first polysomnogram in MZ showing temporal sleep patterns in terms of sleep stages [21]. Genetic background contributes heavily on numerous sleep traits like sleep duration, quality, onset latency, efficiency and wake after sleep onset, REM/NREM sleep characteristics, stage changes, diurnal preference, behavioral reaction due to sleep loss, insomnia and several sleep related disorders like restless leg syndrome [22-25].

NREM sleep is found consistently to be under strong genetic control in humans and animal models as compared to REM sleep [26-28]. REM sleep amount was found to be significantly 
correlated in MZ twins, 95\% heritable in some studies, with conflicting results from other studies [21,23,25,29], sleep onset latency in MZ only [29], sleep efficiency and wake after sleep onset $[18,19,24,29,30]$, stage changes and frequency profiles also in MZ [4,31], diurnal preference [19,32,33], neurobehavioral reaction to sleep loss [24], disorders like insomnia [19,34,35], RLS [36,37], sleep talking, bruxism, enuresis [38-40].

In terms of familial and linkage studies certain sleeprelated diseases show high familial risk and specific modes of transmission, loci and certain molecules.

\section{Familial Advanced Sleep Phase Syndrome (FASPS)}

It shows an $\mathrm{AD}$ pattern of inheritance, characterized by persistent early evening sleep onset and early morning awakening. Although the complaint of awakening earlier than desired is relatively common, particularly in older adults, extreme advance of sleep phase is rare. hPer2, CK1 $1 \varepsilon$, and CK1 $\delta$ has been associated with this syndrome complex $[41,42]$. The circadian rhythms of sleep propensity and melatonin secretion are regulated by a central circadian clock, most importantly the suprachiasmatic nucleus of the hypothalamus along with body core temperature. Reid, et al. used measures of sleep onset and offset, dim light melatonin onset, Horne-Ostberg morningness - eveningness questionnaire and clinical interviews in a 32 member family with ASPS [43].

Autosomal semi-dominant mutations in rodents with fast or slow biological clocks (i.e. short or long endogenous period lengths; tau) are associated with phase-advanced or delayed sleep-wake rhythms, respectively [44]. A known missense mutation (bp2106 A/G) in hPer2 was checked in 2 Japanese families. None of the tested subjects possessed the missense mutation and there was no significant linkage between affected subjects with hPer2 region by 2-point mapping and by direct sequencing of 23 exons of hPer2, supporting the possibility of genetic heterogeneity [45]. Phosphorylation of PER proteins regulates their stability as well as their subcellular localization. Vanselow, et al. have identified 21 phosphorylated residues of mPER2 including Ser 659, which is mutated in patients suffering from FASPS. Phosphorylation at Ser 659 results in nuclear retention and stabilization of mPER2, whereas phosphorylation at other sites leads to MPER2 degradation in oscillating fibroblasts [46].

\section{Restless Legs Syndrome (RLS)}

Diagnostic criteria of RLS is quite simple [47]. Mode of inheritance can be AD, AR and few cases are not clear. AD type comprises of 5 types of RLS (1-5), sequenced to long and short arm of chromosome [48-52,53-58]. Liebetanz, et al. showed fine-mapping of an AD locus in a family of Bavarian origin with intrafamilial heterogeneity with RLS3 [59]. Desautels, et al. examined 276 individuals from 19 families using a selection of markers spanning the identified candidate interval on chromosome 12q. Results also suggested the presence of heterogeneity in RLS as linkage was formally excluded across the region in 6 pedigrees. Significantly higher periodic leg movements during sleep indices were observed for all probands with RLS from linked families showing AR pattern of inheritance of RLS1 [60], unclear inheritance pattern in RLS2 $(12 q, 14 q)$ and related to several other molecules like MEIS1.

Sarayloo, et al. used human cell lines to conduct a RNASeq study. MEIS1, acts as a regulator of the expression of many other genes and some of the genes affected by its expression level are linked to pathways previously reported to be associated with RLS. Cells where MEIS1 expression was either increased or prevented, bone mineral absorption was the principal dysregulated pathway. The mineral absorption main pathway genes, HMOX1 and VDR are involved in iron metabolism and response to vitamin D, respectively. Same enrichment of the mineral absorption pathway in postmortem brain tissues of RLS patients showed a reduced expression of MEIS1. Expression of genes encoding metallothioneins (MTs) was observed to be dysregulated across the RNA-Seq datasets generated from both human cells and tissues in their study. MTs are highly relevant to RLS as they bind intracellular metals, protect against oxidative stress and interact with ferritins which manage iron level in the central nervous system. While MTs have been implicated in the pathogenesis of neurodegenerative diseases such as Parkinson's disease this was the first study showed the molecular association with RLS [61,62].

RLS-linked genetic signal has been mapped to an intronic regulatory element within MEIS1. This element plays a role in the ganglionic eminences of the developing forebrain, with the RLS risk allele related to a reduced activation of the enhancer part. Ganglionic eminences play an important role in the development of genetic susceptibility to RLS. Some rare variants within MEIS1 alone are sufficient to suppress MEIS1 function in neural development, providing further evidence of the importance of neurodevelopmental processes in the pathological mechanism of MEIS1 in RLS. Salminen, et al. 2019 reported heterozygous MEIS1 inactivation in mice causing hyperactivity at the onset of the inactive period, consistent with human RLS. These mice related animal study also revealed an effect of MEIS1 on the dopaminergic system at both the spinal and supraspinal level thereby suggesting complex pathomechanistic process [63], BTBD9, MAP2K5, LBOXCOR1, DMT1 [64-68]. Recently Tilch, et al. has updated the genetic profile of RLS by mutation load analysis previously not reported [69]. TOX3 gene variant could be associated with painful restless legs [70].

\section{Primary Nocturnal Enuresis (PNE)}

Nocturnal enuresis, or nightly bedwetting in children more than seven years of age affects about $10 \%$ of seven-year-old 
children, with a wide range of frequencies between populations. From the age of seven there is a spontaneous cure rate of $15 \%$ per year, such that few remain affected even after the age of 16 years. Two types of nocturnal enuresis exists: type I (PEN1, primary) with at least three nightly episodes in children above seven years, where the child has always had the disorder and type II (secondary) where the child has been dry for at least six months, but enuresis has recurred. Reports from a danish family population, in which 17 families were examined, eleven of these family had type I nocturnal enuresis (PEN1) that appeared to follow an AD mode of inheritance with penetrance almost above $90 \%$. Strong evidence of linkage with the DNA polymorphisms D13S291 and D13S263 was found. Multipoint analysis indicated that these markers flank the disease locus at chromosome 13q13-q14.3 as reported by Eiberg, et al. [71-73]. Arnell, et al. found a region around D12S80 on chromosome $12 \mathrm{q}$ that showed a positive two point lod score in six of the families among sixteen of them. Ratio of males to females was $3: 1$, indicating sex linked or sex influenced factors [74].

Linkage analysis revealed 6 families with dominant primary nocturnal enuresis around the aquaporin-2 (AQP2) water channel locus. PNE is ameliorated by desmopressin, AQP2 expression is increased by desmopressin and AQP2 is essential for concentrating urine. Deen, et al. in their study reported no mutation in the AQP2 coding, the AQP2 gene is excluded as a candidate for autosomal dominant PNE in these families in which the disease co-segregates with chromosome $12 q$ [75]. Eiberg, et al. in their research used total genome scan and multipoint analysis and mapped PNE to chromosome 22 between the markers D22S446 and D22S343 with a multipoint lod score of 4.51.GNAZ has a transducin function in eye and brain and is an obvious candidate gene on chromosome $22 \mathrm{q} 11$ for PNE [76].

Brain-derived neurotrophic factor (BDNF) and nerve growth factor (NGF) are neurotrophins which affects maturation of the nervous system. Delayed neuronal maturation has been suggested as a pathogenetic mechanism in primary monosymptomatic nocturnal enuresis (PMNE). Neurotrophin gene polymorphisms did not significantly contribute to the development of PMNE, but urine levels of neurotrophin gene products were higher in PMNE [77]. Dopamine D4 receptor (DRD4) promoter (-616; rs747302) has been associated with primary nocturnal enuresis (PNE). Yu, et al. reported C-allele carriers were associated with a higher AS (Arousal from Sleep), decreased GMV (Grey Matter Volume) and FCD (Functional Connectivity Density) in the pregenual anterior cingulate cortex. Children with PNE carrying the C-allele exhibit decreased GMV and FCD in the thalamus however, controls who participated in the studies carrying the $\mathrm{C}$ allele exhibit increased FCD in the posterior cingulate cortex. Thus this genetic variation of the DRD4 locus may give a genetic susceptibility of the DRD4-616 C allele to PNE $[78,79]$. Fatouh, et al. reported PNE can be in part linked to reversed ADH circadian rhythm which may be linked to chromosome 22 [80]. The association between 5HTR2A gene polymorphisms and polysymptomatic NE was reported by Wei, et al. suggesting that genetic variations at 5HTR2A may influence NE treatment response [81].

Genetic variations affecting sleep phenotypes include several genes, modifications like SNP, missense mutation, VNTR, insertion/deletion variant, SNPs in promoter and coding region, missense mutation in signal peptide, SNP in $5^{\prime} U T R$. Specific genes are described below:

CLOCK: A transcription-translation feedback loop serves as the basic mechanism for the clock machinery in the suprachiasmatic nucleus (SCN) to control circadian rhythmic city. The PER and CRY proteins, in turn, act as negative regulators of CLOCK/BMAL1 activity by forming a repressor complex with casein kinase (CK) $1 \varepsilon$ (encoded by the CSNK1E gene) and CK1 $\delta$ (CSNK1D) [52,59]. Besides their function in circadian rhythmicity, clock genes have also been found to influence sleep variables. Supporting evidence comes from animal models showing that knockout of BMAL1 and NPAS2 and double knockout of Cry1 and Cry2 lead to abnormalities in sleep homeostasis in animal model [82-84]. In 1998, Katzenberg, found a T3111C polymorphism in the 3 ' UTR of CLOCK associated with diurnal preferences, in that carriers of the $\mathrm{C}$-allele are more often evening- type. In a Japanese sample, the highest eveningness was likewise found in $\mathrm{C} / \mathrm{C}$ homozygous subjects, along with significantly delayed sleep onset, shorter sleep duration, and higher daytime sleepiness compared with either heterozygous or homozygous T- allele carriers [85-93].

SLC6A3(DAT): In humans, a VNTR polymorphism in the 3' UTR of the DAT encoding gene SLC6A3 leads to less DAT in the striatum in individuals homozygous for the long 10repeat allele as compared with carriers of the 9 repeat allele. According to the available animal data, 10/10 carriers are more sensitive to caffeine generally, as well as to its effect on reducing SWS rebound after sleep deprivation, which was found more pronounced in 10- repeat homozygotes [94-98].

MAOA: Monoamine oxidase (MAO) A and B are encoded on the $\mathrm{X}$ - chromosome and catalyze the degradation of serotonin and melatonin. Females carrying an allele conferring higher activity due to a variable number tandem repeat (VNTR) polymorphism in the MAO- A promoter region are at higher risk of developing RLS. The less active allele seems to confer susceptibility to depression and poor sleep quality. Koch, et al. proposed an association of a VNTR in intron 1 of the MAOA gene and a dinucleotide repeat in intron 2 of the MAOB gene with the occurrence of narcolepsy with cataplexy. MAO- A and - B inhibitors are capable of reducing symptoms of narcolepsy such as cataplexy and abnormal REM sleep [99-102,103-106].

ADA: Adenosinergic neurotransmission is suspected to play a major role in the regulation of sleep and wakefulness and their homeostasis in mice and humans. Retey, et al. found 
an increase in slow wave sleep (SWS) during an undisturbed night in $\mathrm{ADA}^{*} 1-2$ carriers resembling the effects of one night of sleep deprivation [107]. This was further accompanied by higher delta power in NREM sleep, which is a marker of sleep need [108-112].

BDNF: Evidence in the recent past suggested increased sleep slow waves after sleep deprivation is a reflection in plastic synaptic processes, and that brain-derived neurotrophic factor (BDNF) is causally involved in their homeostatic regulation. The functional Val66Met polymorphism of the gene encoding pro-BDNF causes impaired activity-dependent secretion of mature BDNF protein. Bachmann, et al. reported about the contribution of BDNF to the regulation of sleep slow wave oscillations and variation in neuronal plasticity modulates NREM sleep intensity in humans [113-124].

PRNP: FFI (Fatal Familial Insomnia) is characterized by disrupted sleep, i.e., loss of sleep spindles and slow wave sleep, and impaired sleep stage organization, as well as progressive reduction of sleep time. Reduced metabolism in thalamic and limbic regions and degeneration of thalamic nuclei has been identified. A missense mutation, a G- to - A transition at codon 178 , leads to substitution of aspartate for asparagine. Two Italian affected kindred revealed an underlying point mutation in the prion protein (PrP) gene (PRNP) on chromosome 20. Creutzfeldt- Jakob disease (CJD) is characterized by the same mutation and accumulation of protease- resistant prion protein plaques, but differs from FFI regarding a polymorphism at codon 129, which is common and leads to either incorporation of a methionine or valine and further to protein isoforms differing in size and glycosylation pattern. While in FFI-affected individuals the mutated allele encodes for methionine, those with CJD express valine on the mutated PRNP allele [125-130].

ADORA: Common genetic variation of ADORA2A is an important determinant of psychomotor vigilance in rested and sleep-deprived state. It also modulates individual responses to caffeine after sleep deprivation. Role for adenosine A (2A) receptors in the effects of prolonged wakefulness on vigilant attention and the sleep EEG [131]. Role of adenosine A2A receptors for sleep in humans, suggest that a common variation in ADORA2A contributes to subjective and objective responses to caffeine on sleep [132].

COMT: A sexual dimorphism and a strong effect of COMT genotype on severity of narcolepsy exists. Women narcoleptics with high COMT activity fell asleep twice as fast as those with low COMT activity during the multiple sleep latency test (MSLT) while the opposite was true for men. COMT genotype also strongly affected the presence of sleep paralysis and the number of REM sleep onsets during the MSLT [99]. Dopaminergic mechanisms contribute to impaired waking functions after sleep loss [133]. The Val158Met polymorphism of COMT modulates the effects of modafinil on the NREM sleep EEG in recovery sleep after prolonged wakefulness. The sleep EEG changes induced by modafinil markedly differ from those of caffeine, showing that pharmacological interference with dopaminergic and adenosinergic neurotransmission during sleep deprivation differently affects sleep homeostasis $[134,135]$.

TNFA: Three SNP of the TNFA promoter and one adjacent microsatellite was investigated by Wieczorek, et al. These results point towards an etiological influence of TNFA alleles in narcolepsy and support previous findings suggesting genetic heterogeneity and differences in pathophysiological characteristics of HLA-DR2 positive and negative narcolepsy [136]. TNF-alpha with 857T was associated with narcolepsy independent of the strong association of DRB1*1501 [137].

PER3: Polymorphism in the PER3 promoter associates with diurnal preference and delayed sleep phase disorder [138-140]. PER3 VNTR polymorphism was not associated with individual differences in neurobehavioral responses to PSD (Partial Sleep Deprivation), although it was related to one marker of sleep homoeostatic response during PSD. PER3 does not contribute to the neurobehavioral effects of chronic sleep loss [141]. PER3 polymorphism differentially influences the effects of sleep deprivation on executive and non-executive function in the early morning. These effects appear to be mediated through homeostatic sleep pressure [142,143]. Individual phase differences in PER3 expression during a constant routine correlate with sleep timing during entrainment. PER3 expression in leukocytes represents a useful molecular marker of the circadian processes governing sleep-wake timing [93].

TNFR2: In a Japanese case control study it was found TNFR2 is likely associated with the susceptibility to narcolepsy. Relationship of TNFR2 and TNF-alpha with the susceptibility to narcolepsy indicates the possibility that an additive effect on the susceptibility to the disorder lies between TNFR2-196R and TNF-alpha (-857T) alleles [144]. Chen, et al. reported increased TNF- $\alpha$ level was associated with narcolepsy in our patients, and that chronic inflammation due to various factors might have led to the increased TNF- $\alpha$ levels found in their patients [145].

HCRT: Hypocretin loci do not contribute significantly to genetic predisposition, however cases of human narcolepsy are associated with a deficient hypocretin system [146]. Hypocretin-specific CD8+ T cells was detected in the blood and cerebrospinal fluid of several patients in a study with narcolepsy [147]. Selective hypocretin receptor 2 agonist (YNT-185) has been shown to ameliorate symptoms of narcolepsy in murine models [148].

GABRA (GABA A receptors): A missense mutation was found in the gene of the beta3 subunit nucleotide polymorphism in a patient with chronic insomnia [149]. Pharmacogenetic experiments are currently leading to an understanding of the circuit mechanisms in the hypothalamus by which zolpidem and similar compounds induce sleep at 
$\alpha 2 \beta \gamma 2$-type GABAA receptors [150]. GABA receptors undergo dynamic and differential changes in the wake-active Orx neurons and the sleep-active MCH neurons as a function of and homeostatic adjustment to their preceding activity and sleep-wake state [151].

HTR2A (5-HT2A receptor): Serotonin (5-HT) 5-HT2A receptor (5-HT2AR) and 5-HT2C receptor (5-HT2CR) in the central nervous system are implicated in a range of normal behaviors (e.g., appetite, sleep) [152]. Job stress and 5-HTR2A receptor gene polymorphisms are associated with sleep quality in physicians. Subjects with high job stress level or/and the -1438G/A GG genotype were more likely to report poor sleep quality, and furthermore, their combination effect on sleep quality was higher than their independent effects [153]. Polymorphisms of 5-HT 2A receptor gene and obstructive sleep apnea was shown in metanalysis $[154,155]$. Joëlle Adrien in one animal study showed the role of serotonin transmission in mice model [106].

SLC6A4 (5-HTT): Tryptophan improved objective sleep efficiency and objective wake after sleep onset irrespective of allelic variation in one study [156]. Tryptophan augmentation may be a valuable treatment strategy for sleep impairments related to genetic deficiencies in 5-HT functioning. A metanalysis demonstrated that 5-HTR-1438 "A" and 5-HTTVNTR "10" alleles were significantly associated with OSAS. The "S" allele of 5-HTTLPR and the "GG" genotype of LEPR conferred protection against OSAS in line with some other researches [157-160].

\section{Discussion}

Sleep as we see is the most complex biological process in human beings. In this article genes associated with sleep is being reviewed in details. MZ are more affected than DZ as evident from the twin studies. Disorders associated with sleep genetics include insomnia, breathing disturbances during sleep (i.e., sleep apnea), movement disorders during sleep (i.e., Restless leg syndrome, Periodic leg movements) and sleep-wake state dissociation disorders (i.e., narcolepsy, Rapid Eye Movement (REM) sleep Behavior Disorder, sleep walking).

Familial and linkage studies also hinted at several diseases like FASPS, RLS, and PNE. Pattern of inheritance can be AD/AR or of unclear origin. Several involved molecules and loci are reported among studies. Genes, modification at cellular level like SNP, VNTR, and missense mutations are also reported in literature and every gene modification can lead to different phenotypic trait related to sleep. Neurotransmitters like adenosine, dopamine, serotonin, GABA are involved along with individual effect and complex interaction among them related to neuroanatomical circuit. Molecules like MAO, COMT, TNF, BDNF, Prion protein, orexin, hypocretin are involved in sleep disorders associated with gene interaction. Circadian CLOCK genes are also reviewed in this article.

\section{Conclusion}

Genetics of sleep are still studied because it is considered as a very complex mechanism in humans. Sleep phenotypes and sleep disorders are controlled by individualised genetic factors. Mechanism of sleep function and pathophysiology behind it is controlled from molecular to organismic behavioral level. Sound sleep is important for proper functioning of individual. Improper sleep can lead to unnecessary stress and can be harbinger of diseases like hypertension, diabetes mellitus etc. and decreased neurocognitive status. Various genes are responsible for sleep disorders however if any single gene involved is not known yet. Sleep studies are quite complicated and even PSG may not be able to pick the diagnosis at initial stage. Genetic sequencing may be of great help in subset of population when diagnosis is not clear. Further studies are required in form of basic and translational research which will involve linking of various disorder phenotypes to normal mechanisms regulating the most basic biological substrates.

\section{Acknowledgement}

Special thanks to my supervisor Professor Dr. Huifang Shang who gave initial ideas and supported me through this research study. I would also like to thank Dr. Swatilekha Roy Sarkar for her valuable feedback on the manuscript and literature screening.

\section{References}

1. Veatch OJ, Malow BA. Review of the Genetic Basis of Sleep and Sleep Disorders. JAMA Neurol. 2014; 71: 1058-1060.

2. van Beijsterveldt CEM, Molenaar PCM, de Geus EJC, Boomsma DI. Heritability of human brain functioning as assessed by electroencephalography. Am J Hum Genet. 1996; 58: 562-573. PubMed: https://www.ncbi.nlm.nih.gov/pubmed/8644716

3. Landolt HP. Genetic determination of sleep EEG profiles in healthy humans. Prog Brain Res. 2011; 193: 51-61.

PubMed: https://www.ncbi.nlm.nih.gov/pubmed/21854955

4. Ambrosius $U$, Lietzenmaier $S$, Wehrle R, Wichniak A, Kalus $S$, et al. Heritability of sleep electroencephalogram. Biol Psychiatry. 2008; 64: 344-348

PubMed: https://www.ncbi.nlm.nih.gov/pubmed/18405882

5. De Gennaro L, Marzano C, Fratello F, Moroni F, Pellicciari MC, et al. The electroencephalographic fingerprint of sleep is genetically determined: a twin study. Ann Neurol. 2008; 64: 455-460.

PubMed: https://www.ncbi.nlm.nih.gov/pubmed/18688819

6. Tafti M, Petit B, Chollet D, Neidhart E, de Bilbao F, et al. Deficiency in short-chain fatty acid beta-oxidation affects theta oscillations during sleep. Nat Genet. 2003; 34: 320-325.

PubMed: https://www.ncbi.nlm.nih.gov/pubmed/12796782

7. Maret S, Franken $P$, Dauvilliers $Y$, Ghyselinck NB, Chambon $P$, et al Retinoic acid signaling affects cortical synchrony during sleep. Science. 2005; 310: 111-113.

PubMed: https://www.ncbi.nlm.nih.gov/pubmed/16210540

8. Ashbrook LH, Krystal AD, Fu YH, Ptáček LJ. Genetics of the human circadian clock and sleep homeostat. Neuropsychopharmacology. 2020; 45: 45-54.

PubMed: https://www.ncbi.nlm.nih.gov/pubmed/31400754 
9. Frank MG. The mystery of sleep function: current perspectives and future directions. Rev Neurosci. 2006; 17: 375-392.

PubMed: https://www.ncbi.nlm.nih.gov/pubmed/17139839

10. Mignot $\mathrm{E}$. Why we sleep: the temporal organization of recovery. PLoS Biol. 2008; 6: e106.

PubMed: https://www.ncbi.nlm.nih.gov/pubmed/18447584

11. Crocker A, Sehgal A. Genetic analysis of sleep. Genes Dev. 2010; 24 : 1220-1235.

12. Cirelli $\mathrm{C}$. The genetic and molecular regulation of sleep: from fruit flies to humans. Nat Rev Neurosci. 2009; 10: 549-560.

PubMed: https://www.ncbi.nlm.nih.gov/pubmed/19617891

13. Andretic R, Franken P, Tafti M. Genetics of sleep. Annu Rev Genet. 2008; 42: 361-388.

PubMed: https://www.ncbi.nlm.nih.gov/pubmed/18983259

14. Allada R, Siegel JM. Unearthing the phylogenetic roots of sleep. Curr Biol. 2008; 18: R670-R679.

PubMed: https://www.ncbi.nlm.nih.gov/pubmed/18682212

15. Partinen M, Kaprio J, Koskenvuo M. Genetic and environmental determination of human sleep. Sleep. 1983; 6: 179-185. PubMed: https://www.ncbi.nlm.nih.gov/pubmed/6684786

16. Gedda L, Brenci G. Twins living apart test: progress report. Acta Genet Med Gemellol (Roma). 1983; 32: 17-22.

PubMed: https://www.ncbi.nlm.nih.gov/pubmed/6684862

17. Gedda L, Brenci G. Sleep and dream characteristics in twins. Acta Genet Med Gemellol (Roma). 1979; 28: 237-239.

PubMed: https://www.ncbi.nlm.nih.gov/pubmed/575840

18. Barclay NL, Eley TC, Buysse DJ. Diurnal preference and sleep quality: same genes? A study of young adult twins. Chronobiol Int. 2010; 27: 278-296.

PubMed: https://www.ncbi.nlm.nih.gov/pubmed/20370470

19. Hublin C, Partinen M, Koskenvuo M, Kaprio J. Heritability and mortality risk of insomnia- related symptoms: a genetic epidemiologic study in a population- based twin cohort. Sleep. 2011; 34: 957-964.

PubMed: https://www.ncbi.nlm.nih.gov/pubmed/21731146

20. Rao WW, Li W, Qi H. Sleep quality in medical students: a comprehensive meta-analysis of observational studies. Sleep Breath. 2020; 10. PubMed: https://www.ncbi.nlm.nih.gov/pubmed/32072469

21. Zung WW, Wilson WP. Sleep and dream patterns in twins. Markov analysis of a genetic trait. Recent Adv Biol Psychiatry. 1966; 9: 119-130. PubMed: https://www.ncbi.nlm.nih.gov/pubmed/4300786

22. Linkowski P, Kerkhofs M, Hauspie R. Genetic determinants of EEG sleep a study in twins living apart. Electroencephalogr Clin Neurophysiol. 1991; 79: 114-118.

PubMed: https://www.ncbi.nlm.nih.gov/pubmed/1713824

23. Linkowski $P$, Kerkhofs $M$, Hauspie R. EEG sleep patterns in mana twin study. Electroencephalogr Clin Neurophysiol. 1989; 73: 279-284. PubMed: https://www.ncbi.nlm.nih.gov/pubmed/2477214

24. Kuna ST, Maislin G, Pack FM. Heritability of performance deficit accumulation during acute sleep deprivation in twins. Sleep. 2012; 35: 12231233

PubMed: https://www.ncbi.nlm.nih.gov/pubmed/22942500

25. Barclay NL, Gregory AM. Quantitative genetic research on sleep: a review of normal sleep, sleep disturbances and associated emotional, behavioural, and health- related difficulties. Sleep Med Rev. 2013; 17: 29-40.

PubMed: https://www.ncbi.nlm.nih.gov/pubmed/22560641

26. Linkowski P. EEG sleep patterns in twins. J Sleep Res. 1999; 8: 11-13.

27. Tafti M, Franken P, Kitahama K. Localization of candidate genomic regions influencing paradoxical sleep in mice. Neuroreport. 1997; 8: 3755-3758.

PubMed: https://www.ncbi.nlm.nih.gov/pubmed/9427364

28. Franken P., Chollet $D$, Tafti $M$. The homeostatic regulation of sleep need is under genetic control. J Neurosci. 2001; 21: 2610-2621. PubMed: https://www.ncbi.nlm.nih.gov/pubmed/11306614

29. Webb WB, Campbell SS. Relationships in sleep characteristics of identical and fraternal twins. Arch Gen Psychiatry. 1983; 40: 1093-1095. PubMed: https://www.ncbi.nlm.nih.gov/pubmed/6684906

30. Boomsma DI, Van Someren EJ, Beem AL. Sleep during a regular week night: a twin- sibling study. Twin Res Hum Genet. 2008; 11: 538-545. PubMed: https://www.ncbi.nlm.nih.gov/pubmed/18828737

31. De Gennaro L, Ferrara M, Vecchio F. An electroencephalographic fingerprint of human sleep. Neuroimage. 2005; 26: 114-122. PubMed: https://www.ncbi.nlm.nih.gov/pubmed/15862211

32. Hur YM. Stability of genetic influence on morningness- eveningness: a cross- sectional examination of South Korean twins from preadolescence to young adulthood. J Sleep Res. 2007; 16: 17-23. PubMed: https://www.ncbi.nlm.nih.gov/pubmed/17309759

33. Koskenvuo $\mathrm{M}$, Hublin $\mathrm{C}$, Partinen $\mathrm{M}$. Heritability of diurnal type: a nationwide study of 8753 adult twin pairs. J Sleep Res. 2007; 16: 156-162. PubMed: https://www.ncbi.nlm.nih.gov/pubmed/17542945

34. Drake CL, Friedman NP, Wright KP Jr, Roth T. Sleep reactivity and insomnia: genetic and environmental influences. Sleep. 2011; 34 1179-1188.

PubMed: https://www.ncbi.nlm.nih.gov/pubmed/21886355

35. Watson NF, Goldberg J, Arguelles L, Buchwald D. Genetic and environmental influences on insomnia, daytime sleepiness, and obesity in twins. Sleep. 2006; 29: 645-649.

PubMed: https://www.ncbi.nlm.nih.gov/pubmed/16774154

36. Xiong L, Jang K, Montplaisir J. Canadian restless legs syndrome twin study. Neurology. 2007; 68: 1631-1633.

PubMed: https://www.ncbi.nlm.nih.gov/pubmed/17485653

37. Desai AV, Cherkas LF, Spector TD, Williams AJ. Genetic influences in self- reported symptoms of obstructive sleep apnoea and restless legs: a twin study. Twin Res. 2004; 7: 589-595.

PubMed: https://www.ncbi.nlm.nih.gov/pubmed/15607009

38. Hublin C, Kaprio J, Partinen M, Koskenvuo M. Sleep talking in twins: epidemiology and psychiatric comorbidity. Behav Genet. 1998; 28: 289298.

39. Hublin C, Kaprio J, Partinen M, Koskenvuo M. Sleep bruxism based on self- report in a nationwide twin cohort. J Sleep Res. 1998; 7: 61-67. PubMed: https://www.ncbi.nlm.nih.gov/pubmed/9613429

40. Hublin C, Kaprio J, Partinen M, Koskenvuo M. Nocturnal enuresis in a nationwide twin cohort. Sleep. 1998; 21: 579-585.

PubMed: https://www.ncbi.nlm.nih.gov/pubmed/9779517

41. Toh $\mathrm{KL}$, Jones $\mathrm{CR}, \mathrm{He} \mathrm{Y}$. An hPer2 phosphorylation site mutation in familial advanced sleep phase syndrome. Science. 2001; 291: 10401043. PubMed: https://www.ncbi.nlm.nih.gov/pubmed/11232563

42. Xu Y, Padiath QS, Shapiro RE. Functional consequences of a CKIठ mutation causing familial advanced sleep phase syndrome. Nature. 2005; 434: 640-644.

PubMed: https://www.ncbi.nlm.nih.gov/pubmed/15800623

43. Reid KJ, Chang AM, Dubocovich ML, Turek FW, Takahashi JS, et al. Familial advanced sleep phase syndrome. Arch Neurol. 2001; 58: 10891094.

PubMed: https://www.ncbi.nlm.nih.gov/pubmed/11448298

44. Jones CR, Campbell SS, Zone SE. Familial advanced sleep-phase syndrome: A short-period circadian rhythm variant in humans. Nat Med. 1999; 5: 1062-1065.

PubMed: https://www.ncbi.nlm.nih.gov/pubmed/10470086 
45. Satoh K, Mishima K, Inoue $Y$, Ebisawa $T$, Shimizu T. Two pedigrees of familial advanced sleep phase syndrome in Japan. Sleep. 2003; 26 416-417.

PubMed: https://www.ncbi.nlm.nih.gov/pubmed/12841366

46. Vanselow K, Vanselow JT, Westermark PO. Differential effects of PER2 phosphorylation: molecular basis for the human familial advanced sleep phase syndrome (FASPS). Genes Dev. 2006; 20: 2660-2672. PubMed: https://www.ncbi.nlm.nih.gov/pubmed/16983144

47. Chen $\mathrm{P}$, ljomone $\mathrm{OM}$, Lee $\mathrm{KH}$, Aschner $\mathrm{M}$. Caenorhabditis elegans and its applicability to studies on restless legs syndrome. Adv Pharmacol. 2019; 84: 14-174.

PubMed: https://www.ncbi.nlm.nih.gov/pubmed/31229169

48. Chen S, Ondo WG, Rao S. Genomewide linkage scan identifies a nove susceptibility locus for restless legs syndrome on chromosome $9 \mathrm{p}$. Am J Hum Genet 2004; 74: 876-885.

PubMed: https://www.ncbi.nlm.nih.gov/pubmed/15077200

49. Vogl FD, Pichler I, Adel S. Restless legs syndrome: epidemiological and clinicogenetic study in a South Tyrolean population isolate. Mov Disord. 2006; 21: 1189-1195.

PubMed: https://www.ncbi.nlm.nih.gov/pubmed/16685686

50. Caylak E. The genetics of sleep disorders in humans: narcolepsy, restless legs syndrome, and obstructive sleep apnea syndrome. Am J Med Genet A. 2009; 149: 2612-2626.

PubMed: https://www.ncbi.nlm.nih.gov/pubmed/19876894

51. Winkelmann J, Muller MB. Genetics of restless legs syndrome: a burning urge to move. Neurology. 2008; 70: 664-645.

PubMed: https://www.ncbi.nlm.nih.gov/pubmed/18299518

52. Winkelmann J, Polo O, Provini F. Genetics of restless legs syndrome (RLS): State-of-the-art and future directions. Mov Disord. 2007; 22 S449-S458.

PubMed: https://www.ncbi.nlm.nih.gov/pubmed/17557342

53. Lohmann HK, Neumann A, Kleensang A. Evidence for linkage of restless legs syndrome to chromosome 9p: are there two distinct loci? Neurology. 2008; 70: 686-694.

PubMed: https://www.ncbi.nlm.nih.gov/pubmed/18032746

54. Levchenko A, Provost S, Montplaisir JY. A novel autosomal dominant restless legs syndrome locus maps to chromosome 20p13. Neurology. 2006; 67: 900-901.

PubMed: https://www.ncbi.nlm.nih.gov/pubmed/16966564

55. Pichler I, Marroni F, Volpato CB. Linkage analysis identifies a novel locus for restless legs syndrome on chromosome $2 q$ in a South Tyrolean population isolate. Am J Hum Genet. 2006; 79: 716-723. PubMed: https://www.ncbi.nlm.nih.gov/pubmed/16960808

56. Desautels A, Turecki G, Montplaisir J. Identification of a major susceptibility locus for restless legs syndrome on chromosome 12q. Am J Hum Genet. 2001; 69: 1266-1270.

PubMed: https://www.ncbi.nlm.nih.gov/pubmed/11704926

57. Bonati MT, Ferini SL, Aridon P. Autosomal dominant restless legs syndrome maps on chromosome 14q. Brain. 2003; 126: 1485-1492. PubMed: https://www.ncbi.nlm.nih.gov/pubmed/12764067

58. Kock N, Culjkovic B, Maniak S. Mode of inheritance and susceptibility locus for restless legs syndrome, on chromosome 12q. Am J Hum Genet. 2002; 71: 205-208.

PubMed: https://www.ncbi.nlm.nih.gov/pubmed/12068378

59. Liebetanz KM, Winkelmann J, Trenkwalder C. RLS3: fine-mapping of an autosomal dominant locus in a family with intrafamilial heterogeneity. Neurology. 2006; 67: 320-321.

PubMed: https://www.ncbi.nlm.nih.gov/pubmed/16864828

60. Desautels A, Turecki G, Montplaisir J. Restless legs syndrome: confirmation of linkage to chromosome $12 q$, genetic heterogeneity, and evidence of complexity. Arch Neurol. 2005; 62: 591-596. PubMed: https://www.ncbi.nlm.nih.gov/pubmed/15824258
61. Sarayloo F, Dionne LA, Catoire H. Mineral absorption is an enriched pathway in a brain region of restless legs syndrome patients with reduced MEIS1 expression. PLoS One. 2019; 14: e0225186. PubMed: https://www.ncbi.nlm.nih.gov/pubmed/31725784

62. Sarayloo F, Dion PA, Rouleau GA. MEIS1 and Restless Legs Syndrome: A Comprehensive Review. Front Neurol. 2019; 10: 935.

PubMed: https://www.ncbi.nlm.nih.gov/pubmed/31551905

63. Salminen AV, Lam DD, Winkelmann J. Role of MEIS1 in restless legs syndrome: From GWAS to functional studies in mice. Adv Pharmacol. 2019; 84: 175-184.

PubMed: https://www.ncbi.nlm.nih.gov/pubmed/31229170

64. Levchenko A, Montplaisir JY, Dube MP. The $14 q$ restless legs syndrome locus in the French Canadian population. Ann Neurol. 2004; 55: 887891.

PubMed: https://www.ncbi.nlm.nih.gov/pubmed/15174026

65. Winkelmann J, Lichtner P, Putz B. Evidence for further genetic locus heterogeneity and confirmation of RLS-1 in restless legs syndrome. Mov Disord. 2006; 21: 28-33.

PubMed: https://www.ncbi.nlm.nih.gov/pubmed/16124010

66. Winkelmann J, Schormair B, Lichtner P. Genome- wide association study of restless legs syndrome identifies common variants in three genomic regions .Nat Genet. 2007; 39: 1000-1006. PubMed: https://www.ncbi.nlm.nih.gov/pubmed/17637780

67. Xiong L, Dion P, Montplaisir J. Molecular genetic studies of DMT1 on 12q in French-Canadian restless legs syndrome patients and families. Am J Med Genet B Neuropsychiatr Genet. 2007; 144: 911-917. PubMed: https://www.ncbi.nlm.nih.gov/pubmed/17510944

68. Stefansson $H$, Rye DB, Hicks A. A genetic risk factor for periodic limb movements in sleep. N Engl J Med. 2007; 357: 639-647. PubMed: https://www.ncbi.nlm.nih.gov/pubmed/17634447

69. Tilch E, Schormair B, Zhao C. Identification of Restless Legs Syndrome Genes by Mutational Load Analysis. Ann Neurol. 2020; 87: 184-193. PubMed: https://www.ncbi.nlm.nih.gov/pubmed/31788832

70. Karroum EG, Saini PS, Trotti LM, Rye DB. TOX3 gene variant could be associated with painful restless legs. Sleep Med. 2020; 65: 4-7. PubMed: https://www.ncbi.nlm.nih.gov/pubmed/31706190

71. Eiberg H, Berendt I, Mohr J. Assignment of dominant inherited nocturnal enuresis (ENUR1) to chromosome 13q. Nat Genet. 1995; 10: 354-356. PubMed: https://www.ncbi.nlm.nih.gov/pubmed/7670476

72. Eiberg H, Shaumburg HL, Von Gontard A, Rittig S. Linkage study of a large Danish 4- generation family with urge incontinence and nocturnal enuresis. J Urol. 2001; 166: 2401-2403.

PubMed: https://www.ncbi.nlm.nih.gov/pubmed/11696797

73. Von GA, Eiberg H, Hollmann E. Molecular genetics of nocturnal enuresis: clinical and genetic heterogeneity. Acta Paediatr. 1998; 87: 571-578

PubMed: https://www.ncbi.nlm.nih.gov/pubmed/9641742

74. Arnell $\mathrm{H}$, Hjalmas $\mathrm{K}$, Jagervall $\mathrm{M}$. The genetics of primary nocturnal enuresis: inheritance and suggestion of a second major gene on chromosome 12q. J Med Genet. 1997; 34: 360-365.

PubMed: https://www.ncbi.nlm.nih.gov/pubmed/9152831

75. Deen PM, Dahl N, Caplan MJ. The aquaporin- 2 water channel in autosomal dominant primary nocturnal enuresis. J Urol. 2002; 167: 1447-1450.

PubMed: https://www.ncbi.nlm.nih.gov/pubmed/11832768

76. Eiberg $\mathrm{H}$. Total genome scan analysis in a single extended family for primary nocturnal enuresis: evidence for a new locus (ENUR3) for primary nocturnal enuresis on chromosome 22q11. Eur Urol. 1998; 33: 34-36.

PubMed: https://www.ncbi.nlm.nih.gov/pubmed/9599735 
77. Ece A, Coşkun S, Şahin C, Tan I, Karabel D, et al. BDNF and NGF gene polymorphisms and urine BDNF-NGF levels in children with primary monosymptomatic nocturnal enuresis. J Pediatr Urol. 2019; 15: 255. e1-255.e7.

PubMed: https://www.ncbi.nlm.nih.gov/pubmed/30981636

78. Yu B, Chang N, Lu Y, Ma H, Liu N, et al. Effect of DRD4 receptor $-616 \mathrm{C} / \mathrm{G}$ polymorphism on brain structure and functional connectivity density in pediatric primary nocturnal enuresis patients. Sci Rep. 2017; 7: 1226. PubMed: https://www.ncbi.nlm.nih.gov/pubmed/28450726

79. Dai XM, Ma HW, Lu Y, Pan XX. Relationship between dopamine D4 receptor gene polymorphisms and primary nocturnal enuresis. Zhongguo Dang Dai Er Ke Za Zhi. 2008; 10: 607-610.

PubMed: https://www.ncbi.nlm.nih.gov/pubmed/18947481

80. Fatouh AA, Motawie AA, Abd Al-Aziz AM. Anti-diuretic hormone and genetic study in primary nocturnal enuresis. J Pediatr Urol. 2013; 9: 831-837.

PubMed: https://www.ncbi.nlm.nih.gov/pubmed/23246575

81. Wei CC, Wan L, Lin WY, Tsai FJ. Rs 6313 polymorphism in 5-hydroxytryptamine receptor $2 \mathrm{~A}$ gene association with polysymptomatic primary nocturnal enuresis. J Clin Lab Anal. 2010; 24: 371-375. PubMed: https://www.ncbi.nlm.nih.gov/pubmed/21089166

82. Wisor JP, O'Hara BF, Terao A. A role for cryptochromes in sleep regulation. BMC Neurosci. 2002; 3: 20.

PubMed: https://www.ncbi.nlm.nih.gov/pubmed/12495442

83. Franken P, Dudley CA, Estill SJ. NPAS2 as a transcriptional regulator of non- rapid eye movement sleep: genotype and sex interactions. Proc Natl Acad Sci USA. 2006; 103: 7118-7123.

PubMed: https://www.ncbi.nlm.nih.gov/pubmed/16636276

84. Laposky A, Easton A, Dugovic C. Deletion of the mammalian circadian clock gene BMAL1/ Mop3 alters baseline sleep architecture and the response to sleep deprivation. Sleep. 2005; 28: 395-409.

PubMed: https://www.ncbi.nlm.nih.gov/pubmed/16171284

85. Katzenberg D, Young T, Finn L. A CLOCK polymorphism associated with human diurnal preference. Sleep. 1998; 21: 569-576.

PubMed: https://www.ncbi.nlm.nih.gov/pubmed/9779516

86. Mishima K, Tozawa T, Satoh K. The $3111 \mathrm{~T} / \mathrm{C}$ polymorphism of hClock is associated with evening preference and delayed sleep timing in a Japanese population sample. Am J Med Genet B Neuropsychiatr Genet. 2005; 133B: 101-104.

PubMed: https://www.ncbi.nlm.nih.gov/pubmed/15578592

87. Morris AR, Stanton DL, Roman D, Liu AC. Systems Level Understanding of Circadian Integration with Cell Physiology. J Mol Biol. 2020.

PubMed: https://www.ncbi.nlm.nih.gov/pubmed/32061938

88. Hor CN, Yeung J, Jan $M$, et al. Sleep-wake-driven and circadian contributions to daily rhythms in gene expression and chromatin accessibility in the murine cortex. Proc Natl Acad Sci USA. 2019; 116: 25773-25783.

PubMed: https://www.ncbi.nlm.nih.gov/pubmed/31776259

89. Charrier A, Olliac B, Roubertoux P, Tordjman S. Clock Genes and Altered Sleep-Wake Rhythms: Their Role in the Development of Psychiatric Disorders. Int J Mol Sci. 2017; 18: 938.

PubMed: https://www.ncbi.nlm.nih.gov/pubmed/28468274

90. Von Schantz M, Archer SN. Clocks, genes and sleep. J R Soc Med 2003; 96: 486-489.

PubMed: https://www.ncbi.nlm.nih.gov/pubmed/14519724

91. Landgraf $D$, Shostak $A$, Oster H. Clock genes and sleep. Pflugers Arch. 2012; 463: 3-14.

PubMed: https://www.ncbi.nlm.nih.gov/pubmed/21833490

92. Comasco E, Nordquist N, Göktürk C. The clock gene PER2 and sleep problems: association with alcohol consumption among Swedish adolescents. Ups J Med Sci. 2010; 115: 41-48.

PubMed: https://www.ncbi.nlm.nih.gov/pubmed/20187847
93. Archer. Inter-Individual Differences In Habitual Sleep Timing and Entrained Phase of Endogenous Circadian Rhythms of BMAL1, PER2 and PER3 mRNA in Human Leukocytes. Sleep. 2008; 31: 608-617. PubMed: https://www.ncbi.nlm.nih.gov/pubmed/18517031

94. Holst SC, Bersagliere A, Bachmann V. Dopaminergic role in regulating neurophysiological markers of sleep homeostasis in humans. J Neurosci. 2014; 34: 566-573.

PubMed: https://www.ncbi.nlm.nih.gov/pubmed/24403155

95. Rhodes JA, Lane JM, Vlasac IM, Rutter MK, Czeisler CA, et al Association of DAT1 genetic variants with habitual sleep duration in the UK Biobank. Sleep. 2019; 42: zsy193.

PubMed: https://www.ncbi.nlm.nih.gov/pubmed/30299516

96. Satterfield BC, Wisor JP, Schmidt MA, Van Dongen HPA. Time-on-Task Effect During Sleep Deprivation in Healthy Young Adults Is Modulated by Dopamine Transporter Genotype. Sleep. 2017; 40: zsx167. PubMed: https://www.ncbi.nlm.nih.gov/pubmed/29029252

97. Holst SC, Müller T, Valomon A, Seebauer B, Berger W, et al. Functional Polymorphisms in Dopaminergic Genes Modulate Neurobehavioral and Neurophysiological Consequences of Sleep Deprivation. Sci Rep. 2017; 7: 45982

PubMed: https://www.ncbi.nlm.nih.gov/pubmed/28393838

98. Costa A, Riedel M, Muller U. Relationship between SLC6A3 genotype and striatal dopamine transporter availability: a meta- analysis of human single photon emission computed tomography studies. Synapse. 2011; 65: 998-1005.

PubMed: https://www.ncbi.nlm.nih.gov/pubmed/21404331

99. Dauvilliers $Y$, Neidhart $E$, Lecendreux $M$. MAO- A and COMT polymorphisms and gene effects in narcolepsy. Mol Psychiatry. 2001; 6: 367-372.

PubMed: https://www.ncbi.nlm.nih.gov/pubmed/11443519

100. Brummett BH, Krystal AD, Siegler IC. Associations of a regulatory polymorphism of monoamine oxidase- A gene promoter (MAOAuVNTR) with symptoms of depression and sleep quality. Psychosom Med. 2007; 69: 396-401.

PubMed: https://www.ncbi.nlm.nih.gov/pubmed/17585061

101. Desautels A, Turecki G, Montplaisir J. Evidence for a genetic association between monoamine oxidase $A$ and restless legs syndrome. Neurology. 2002; 59: 215-219.

PubMed: https://www.ncbi.nlm.nih.gov/pubmed/12136060

102. Koch H, Craig I, Dahlitz M. Analysis of the monoamine oxidase genes and the Norrie disease gene locus in narcolepsy. Lancet. 1999; 353: 645-646.

PubMed: https://www.ncbi.nlm.nih.gov/pubmed/10030338

103. Kozochkin DA, Manukhina EB, Downey HF. The role of microsomal oxidation in the regulation of monoamine oxidase activity in the brain and liver of rats. Gen Physiol Biophys. 2017; 36: 455-464.

PubMed: https://www.ncbi.nlm.nih.gov/pubmed/28653655

104. Wang Z, Chen L, Zhang L, Wang X. Paradoxical sleep deprivation modulates depressive-like behaviors by regulating the MAOA levels in the amygdala and hippocampus. Brain Res. 2017; 1664: 17-24. PubMed: https://www.ncbi.nlm.nih.gov/pubmed/28365314

105. Ozen F, Yegin Z, Yavlal F, Saglam ZA, Koc H, et al. Lack of association between MAOA-uVNTR variants and excessive daytime sleepiness. Neurol Sci. 2017; 38: 769-774

PubMed: https://www.ncbi.nlm.nih.gov/pubmed/28181067

106. Joëlle A. Sleep and waking in mutant mice that do not express various proteins involved in serotonergic neurotransmission such as the serotonergic transporter, monoamine oxidase $\mathrm{A}$, and 5-HT1A, 5-HT1B, 5-HT2A, 5-HT2C and 5-HT7 receptors Serotonin and Sleep. Molecular, Functional and Clinical Aspects. 2008.

107. Retey JV, Adam M, Honegger E. A functional genetic variation of adenosine deaminase affects the duration and intensity of deep 
sleep in humans. Proc Natl Acad Sci USA. 2005; 102: 15676-15681. PubMed: https://www.ncbi.nlm.nih.gov/pubmed/16221767

108. Bachmann V, Klaus F, Bodenmann S. Functional ADA polymorphism increases sleep depth and reduces vigilant attention in humans. Cereb Cortex. 2012; 22: 962-970.

PubMed: https://www.ncbi.nlm.nih.gov/pubmed/21734253

109. Radulovacki M. Role of adenosine in sleep in rats. Rev Clin Basic Pharm. 1985; 5: 327-339.

PubMed: https://www.ncbi.nlm.nih.gov/pubmed/3916307

110. Porkka-Heiskanen T. Adenosine in sleep and wakefulness. Ann Med. 1999; 31: 125-129.

PubMed: https://www.ncbi.nlm.nih.gov/pubmed/10344585

111. Mazzotti DR, Guindalini C, de Souza AA. Adenosine deaminase polymorphism affects sleep EEG spectral power in a large epidemiological sample. PLoS One. 2012; 7: e44154.

PubMed: https://www.ncbi.nlm.nih.gov/pubmed/22952909

112. Mackiewicz M, Nikonova EV, Bell CC. Activity of adenosine deaminase in the sleep regulatory areas of the rat CNS. Brain Res Mol Brain Res. 2000; 80: 252-255.

PubMed: https://www.ncbi.nlm.nih.gov/pubmed/11038259

113. Bachmann V, Klein C, Bodenmann S. The BDNF Val66Met polymorphism modulates sleep intensity: EEG frequency- and statespecificity. Sleep. 2012; 35: 335-344.

PubMed: https://www.ncbi.nlm.nih.gov/pubmed/22379239

114. Furihata R, Saitoh K, Otsuki R. Association between reduced serum BDNF levels and insomnia with short sleep duration among female hospital nurses. Sleep Med. 2019; 68: 167-172.

PubMed: https://www.ncbi.nlm.nih.gov/pubmed/32044553

115. Flores KR, Viccaro F, Aquilini M. Protective role of brain derived neurotrophic factor (BDNF) in obstructive sleep apnea syndrome (OSAS) patients. PLoS One. 2020; 15: e0227834.

PubMed: https://www.ncbi.nlm.nih.gov/pubmed/31951637

116. Rahmani M, Rahmani F, Rezaei N. The Brain-Derived Neurotrophic Factor: Missing Link between Sleep Deprivation, Insomnia, and Depression. Neurochem Res. 2020; 45: 221-231.

PubMed: https://www.ncbi.nlm.nih.gov/pubmed/31782101

117. Cullen T, Thomas G, Wadley AJ. Sleep Deprivation: Cytokine and Neuroendocrine Effects on Perception of Effort. Med Sci Sports Exerc. 2019.

PubMed: https://www.ncbi.nlm.nih.gov/pubmed/31764462

118. Tchekalarova J, Kortenska L, Ivanova $\mathrm{N}$, Atanasova $\mathrm{M}$, Marinov $\mathrm{P}$. Agomelatine treatment corrects impaired sleep-wake cycle and sleep architecture and increases MT1 receptor as well as BDNF expression in the hippocampus during the subjective light phase of rats exposed to chronic constant light. Psychopharmacology (Berl). 2020; 237: 503-518. PubMed: https://www.ncbi.nlm.nih.gov/pubmed/31720718

119. Sun W, Li J, Cui S, Luo L, Huang P, et al. Sleep Deprivation Disrupts Acquisition of Contextual Fear Extinction by Affecting Circadian Oscillation of Hippocampal-Infralimbic proBDNF. eNeuro. 2019; 6: 0165-0219.

PubMed: https://www.ncbi.nlm.nih.gov/pubmed/31585927

120. Mahboubi S, Nasehi M, Imani A, Sadat-Shirazi MS, Zarrindast MR, et al. Benefit effect of REM-sleep deprivation on memory impairment induced by intensive exercise in male wistar rats: with respect to hippocampal BDNF and TrkB. Nat Sci Sleep. 2019; 11: 179-188. PubMed: https://www.ncbi.nlm.nih.gov/pubmed/31576186

121. Sweeten BLW, Sutton AM, Wellman LL, Sanford LD. Predicting stress resilience and vulnerability: brain-derived neurotrophic factor and rapid eye movement sleep as potential biomarkers of individual stress responses. Sleep. 2020; 43: 199.

PubMed: https://www.ncbi.nlm.nih.gov/pubmed/31556950
122. Staats R. Regulation of brain-derived neurotrophic factor (BDNF) during sleep apnoea treatment. Thorax. 2005; 60: 688-692. PubMed: https://www.ncbi.nlm.nih.gov/pubmed/16061712

123. Karen S, Edith HT, Anne E. BDNF in sleep, insomnia, and sleep deprivation. Annals of Medicine. 2016; 48: 42-51. PubMed: https://www.ncbi.nlm.nih.gov/pubmed/26758201

124. Duncan WC, Sarasso S, Ferrarelli F. Concomitant BDNF and sleep slow wave changes indicate ketamine-induced plasticity in major depressive disorder. Int J Neuropsychopharmacol. 2013; 16: 301-311. PubMed: https://www.ncbi.nlm.nih.gov/pubmed/22676966

125. Medori R, Montagna $\mathrm{P}$, Tritschler HJ, LeBlanc A, Cortelli $\mathrm{P}$, et al. Fatal familial insomnia: a second kindred with mutation of prion protein gene at codon 178. Neurology. 1992; 42: 669-670. PubMed: https://www.ncbi.nlm.nih.gov/pubmed/1347910

126. Monari L, Chen SG, Brown $P$, Parchi $P$, Petersen RB, et al. Fatal familial insomnia and familial Creutzfeldt- Jakob disease: different prion proteins determined by a DNA polymorphism. Proc Natl Acad Sci U S A. 1994; 91: 2839-2842.

PubMed: https://www.ncbi.nlm.nih.gov/pubmed/7908444

127. da Luz MHM, Pino JMV, Santos TG, Antunes HKM, Martins VR, et al. Sleep deprivation regulates availability of PrPC and $A \beta$ peptides which can impair interaction between PrPC and laminin and neuronal plasticity. J Neurochem. 2020; e14960.

PubMed: https://www.ncbi.nlm.nih.gov/pubmed/31950499

128. He R, Hu Y, Yao L, Tian Y, Zhou Y, et al. Clinical features and genetic characteristics of two Chinese pedigrees with fatal family insomnia. Prion. 2019; 13: 116-123.

PubMed: https://www.ncbi.nlm.nih.gov/pubmed/31122137

129. Abu-Rumeileh S, Redaelli V, Baiardi S, Mackenzie G, Windl O, et al. Sporadic Fatal Insomnia in Europe: Phenotypic Features and Diagnostic Challenges. Ann Neurol. 2018; 84: 347-360. PubMed: https://www.ncbi.nlm.nih.gov/pubmed/30048013

130. Goldfarb LG, Petersen RB, Tabaton M, Brown P, LeBlanc AC, et al. Fatal familial insomnia and familial Creutzfeldt- Jakob disease: disease phenotype determined by a DNA polymorphism. Science. 1992; 258: 806-808.

PubMed: https://www.ncbi.nlm.nih.gov/pubmed/1439789

131. Bodenmann S, Hohoff C, Freitag C, Deckert J, Rétey JV, et al Polymorphisms of ADORA2A modulate psychomotor vigilance and the effects of caffeine on neurobehavioural performance and sleep EEG after sleep deprivation. Br J Pharmacol. 2012; 165: 1904-1913. PubMed: https://www.ncbi.nlm.nih.gov/pubmed/21950736

132. Retey JV, Adam M, Khatami R, Luhmann UF, Jung HH, et al. A genetic variation in the adenosine $A 2 A$ receptor gene (ADORA2A) contributes to individual sensitivity to caffeine effects on sleep. Clin Pharmacol Ther. 2007; 81: 692-698

PubMed: https://www.ncbi.nlm.nih.gov/pubmed/17329997

133. Bodenmann S, Xu S, Luhmann UF, Arand M, Berger W, et al. Pharmacogenetics of modafinil after sleep loss: catechol- Omethyltransferase genotype modulates waking functions but not recovery sleep. Clin Pharmacol Ther. 2009; 85: 296-304. PubMed: https://www.ncbi.nlm.nih.gov/pubmed/19037200

134. Bodenmann S, Landolt HP. Effects of modafinil on the sleep EEG depend on Val158Met genotype of COMT. Sleep. 2010; 33: 1027-1035 PubMed: https://www.ncbi.nlm.nih.gov/pubmed/20815183

135. Goel N, Banks S, Lin L. Catechol- O- methyltransferase Val158Met polymorphism associates with individual differences in sleep physiologic responses to chronic sleep loss. PLoS One. 2011; 6: e29283.

PubMed: https://www.ncbi.nlm.nih.gov/pubmed/22216231

136. Wieczorek S, Gencik M, Rujescu D, Tonn P, Giegling I, et al. TNFA 
promoter polymorphisms and narcolepsy. Tissue Antigens. 2003; 61: 437-442.

PubMed: https://www.ncbi.nlm.nih.gov/pubmed/12823767

137. Hohjoh $\mathrm{H}$, Nakayama $\mathrm{T}$, Ohashi J. Significant association of a single nucleotide polymorphism in the tumor necrosis factor- alpha (TNFalpha) gene promoter with human narcolepsy. Tissue Antigens. 1999; 54: 138-145.

PubMed: https://www.ncbi.nlm.nih.gov/pubmed/10488740

138. Archer SN, Carpen JD, Gibson M, Lim GH, Johnston JD, et al. Polymorphism in the PER3 promoter associates with diurnal preference and delayed sleep phase disorder. Sleep. 2010; 33: 695-701.

PubMed: https://www.ncbi.nlm.nih.gov/pubmed/20469812

139. Archer SN, Robilliard DL, Skene DJ, Smits M, Williams A, et al. A length polymorphism in the circadian clock gene Per3 is linked to delayed sleep phase syndrome and extreme diurnal preference. Sleep. 2003; 26: 413-415.

PubMed: https://www.ncbi.nlm.nih.gov/pubmed/12841365

140. Ebisawa T, Uchiyama M, Kajimura N, Mishima K, Kamei $Y$, et al. Association of structural polymorphisms in the human period3 gene with delayed sleep phase syndrome. EMBO Rep. 2001; 2: 342-346. PubMed: https://www.ncbi.nlm.nih.gov/pubmed/11306557

141. Goel N, Banks S, Mignot E, Dinges DF. PER3 polymorphism predicts cumulative sleep homeostatic but not neurobehavioral changes to chronic partial sleep deprivation. PLoS One. 2009; 4: e5874. PubMed: https://www.ncbi.nlm.nih.gov/pubmed/19516903

142. Groeger JA, Viola AU, Lo JC. Early morning executive functioning during sleep deprivation is compromised by a PERIOD3 polymorphism. Sleep. 2008; 31: 1159-1167.

PubMed: https://www.ncbi.nlm.nih.gov/pubmed/18714788

143. Viola AU, Archer SN, James LM, Groeger JA, Lo JC. PER3 polymorphism predicts sleep structure and waking performance. Curr Biol. 2007; 17: 613-618.

PubMed: https://www.ncbi.nlm.nih.gov/pubmed/17346965

144. Hohjoh H, Terada N, Kawashima M, Honda Y, Tokunaga K. Significant association of the tumor necrosis factor receptor 2 (TNFR2) gene with human narcolepsy. Tissue Antigens. 2000; 56: 446-448.

PubMed: https://www.ncbi.nlm.nih.gov/pubmed/11144293

145. Chen $\mathrm{YH}$, Huang $\mathrm{YS}$, Chen $\mathrm{CH}$. Increased plasma level of tumor necrosis factor $\mathrm{a}$ in patients with narcolepsy in Taiwan. Sleep Med. 2013; 14: 1272-1276.

PubMed: https://www.ncbi.nlm.nih.gov/pubmed/24157100

146. Peyron C, Faraco J, Rogers W, Ripley B, Overeem S, et al. A mutation in a case of early onset narcolepsy and a generalized absence of hypocretin peptides in human narcoleptic brains. Nat Med. 2000; 6: 991-997.

PubMed: https://www.ncbi.nlm.nih.gov/pubmed/10973318

147. Latorre D, Kallweit U, Armentani E, Foglierini M1, Mele F, et al. T cells in patients with narcolepsy target self-antigens of hypocretin neurons. Nature. 2018; 562: 63-68.

PubMed: https://www.ncbi.nlm.nih.gov/pubmed/30232458

148. Takenoshita S, Sakai N, Chiba Y, Matsumura M, Yamaguchi M, et al. An overview of hypocretin based therapy in narcolepsy. Expert Opin Investig Drugs. 2018; 27: 389-406.

PubMed: https://www.ncbi.nlm.nih.gov/pubmed/29623725
149. Buhr A, Bianchi MT, Baur R. Functional characterization of the new human GABA A receptor mutation $\beta 3$ (R192H). Hum Genet. 2002; 111: 154-160.

PubMed: https://www.ncbi.nlm.nih.gov/pubmed/12189488

150. Wisden W, Yu X, Franks NP. GABA Receptors and the Pharmacology of Sleep. Handb Exp Pharmacol. 2019; 253: 279-304.

PubMed: https://www.ncbi.nlm.nih.gov/pubmed/28993837

151. Toossi H, Del Cid-Pellitero E, Jones BE. GABA Receptors on Orexin and Melanin-Concentrating Hormone Neurons Are Differentially Homeostatically Regulated Following Sleep Deprivation. eNeuro. 2016; 3: 0077-0116.

PubMed: https://www.ncbi.nlm.nih.gov/pubmed/27294196

152. Felsing DE, Anastasio NC, Miszkiel JM, Gilbertson SR, Allen JA, et al. Biophysical validation of serotonin 5-HT2A and 5-HT2C receptor interaction. PLoS One. 2018; 13: e0203137. PubMed: https://www.ncbi.nlm.nih.gov/pubmed/30157263

153. Gao X, Ge H, Jiang Y, Lian Y, Zhang C, et al. Relationship between Job Stress and 5-HT2A Receptor Polymorphisms on Self-Reported Sleep Quality in Physicians in Urumqi (Xinjiang, China): A Cross-Sectional Study. Int J Environ Res Public Health. 2018; 15: 1034. PubMed: https://www.ncbi.nlm.nih.gov/pubmed/29883419

154. Zhao Y, Tao L, Nie P, Lu X, Xu X, et al. Association between 5- HT $2 A$ receptor polymorphisms and risk of obstructive sleep apnea and hypopnea syndrome: a systematic review and meta- analysis. Gene. 2013; 530: 287-294.

PubMed: https://www.ncbi.nlm.nih.gov/pubmed/23988500

155. Wu Y, Liu HB, Ding M, Liu JN, Zhu XF, et al. Association between the $-1438 \mathrm{G} / \mathrm{A}$ and $\mathrm{T} 102 \mathrm{C}$ polymorphisms of 5 - HT 2A receptor gene and obstructive sleepapnea:a meta- analysis. Mol Biol Rep. 2013; 40: 6223-6231.

PubMed: https://www.ncbi.nlm.nih.gov/pubmed/24065538

156. Van Dalfsen JH, Markus CR. The serotonin transporter gene-linked polymorphic region (5-HTTLPR) and the sleep-promoting effects of tryptophan: A randomized placebo-controlled crossover study. J Psychopharmacol. 2019; 33: 948-954.

PubMed: https://www.ncbi.nlm.nih.gov/pubmed/31237183

157. Barclay NL, Eley TC, Mill J. Sleep quality and diurnal preference in a sample of young adults: associations with 5HTTLPR, PER3, and CLOCK 3111. Am J Med Genet B Neuropsychiatr Genet. 2011; 156 : 681-690.

PubMed: https://www.ncbi.nlm.nih.gov/pubmed/21714069

158. Brummett BH, Krystal AD, Ashley-Koch A, Kuhn CM, Züchner S, et al Sleep quality varies as a function of 5 - HTTLPR genotype and stress. Psychosom Med. 2007; 69: 621-624.

PubMed: https://www.ncbi.nlm.nih.gov/pubmed/17766685

159. Carskadon MA, Sharkey KM, Knopik VS, McGeary JE. Short sleep as an environmental exposure: a preliminary study associating 5- HTTLPR genotype to self- reported sleep duration and depressed mood in firstyear university students. Sleep. 2012; 35: 791-796. PubMed: https://www.ncbi.nlm.nih.gov/pubmed/22654198

160. Deuschle M, Schredl M, Schilling C, Wüst S, Frank J, et al. Association between a serotonin transporter length polymorphism and primary insomnia. Sleep. 2010; 33: 343-347.

PubMed: https://www.ncbi.nlm.nih.gov/pubmed/20337192 